\title{
ANALYSIS AND MANAGEMENT OF MAINTENANCE AND REPAIR WORKS IN RESIDENTIAL BUILDING
}

\author{
Snehal N Mandlik \\ M.E. Student Construction and Management \\ D Y Patil Institute of Engineering and Technology, Ambi, Pune, Maharashtra, India \\ Prof. Hemant H Salunkhe \\ Professor Department of Civil Engineering management \\ D Y Patil Institute of Engineering and Technology, Ambi, Pune, Maharashtra, India
}

\begin{abstract}
Poor and improper building maintenance will cause more damages and costly repair works if ignored. Aging, obsolescence and general deterioration of buildings and their systems and components can adversely affect the ability of building to sustain and operate properly. Priorities should be set for various aspects of maintenance works. This paper explores the different causes of need for maintenance and repair work and strategies of maintenance management in residential building. First of all questionnaire is prepared based on literature study and then data is collected from residents of building by interviewing them. Data analysis based software is used for processing the collected data in different criteria e. g. undamaged, slightly damaged, considerably damaged and severely damaged building components. The paper concludes with the finding out major contributors in maintenance and repair of building and recommendations for those building components.
\end{abstract}

Key words: Building components, building maintenance, critical maintenance components, maintenance and repair works

\section{INTRODUCTION}

\subsection{Maintenance of building}

The main function of building is to protect the occupants and contents from weather, mainly rain, wind and extreme temperatures. Building maintenance is work undertaken to keep, restore or improve every part of building, its services to a currently acceptable standard and to sustain utility and value of the facility. Poor and improper building maintenance will definitely cause more damages and costly repair works if left unattended.

Types of Maintenance

1) Preventive maintenance - The care and servicing by personnel for the purpose of maintaining building component in satisfactory operating condition by providing for systematic inspection, detection, and correction of incipient failures either before they occur or before they develop into major defects. The work carried out on equipment in order to avoid its breakdown or malfunction. It is a regular and routine action taken in building. Preventive Maintenance, including tests, measurements, adjustments, parts replacement, and cleaning, performed specifically to prevent faults from occurring.

2) Corrective maintenance - Corrective maintenance is a maintenance task performed to identify, isolate, and rectify a fault so that the failed building component can be restored to an operational condition. Corrective maintenance can be either planned or unplanned.

3) Condition based maintenance - Condition-based maintenance $(\mathrm{CBM})$ is a maintenance strategy that monitors the actual condition of the building component to decide what maintenance needs to be done. Condition-based maintenance suggests that maintenance should only be performed when certain indicators show signs of decreasing performance or upcoming failure. Condition based maintenance is performed only after a decrease in the condition of the component has been observed. The goal of condition based maintenance is to spot upcoming component failure so maintenance can be proactively scheduled when it is needed - and not before.

4) Planned maintenance - The aim of planned maintenance is to carry out repairs with the goal of keeping the building components from failing. 
Planned maintenance is an asset management strategy to ensure buildings and their components function adequately, preserve the value of the building, satisfy legal obligations, and achieve best value in terms of built assets during the occupancy phase of the building.

\subsection{Repair of building}

Repair is the process of restoration of broken or damaged part or property to an acceptable operating condition.

\section{Types of repair services}

1) Day to day repair - The purpose of this maintenance service is to ensure satisfactory continuous functioning of various services in the buildings.

Examples for such repairs are removing blocks of drainage pipes, manholes, restoration of water supply, repairs to faulty switches, watering of plants, lawn mowing, hedge cutting, sweeping of leaf falls etc.

2) Annual repair - This maintenance service is carried out to maintain the aesthetics of buildings and services as well as to preserve their life, some works like white washing, distempering, painting, cleaning of lines, tanks etc. are carried out periodically

3) Special repair - Special repairs of building are undertaken to replace the existing parts of buildings and services which get deteriorated on ageing of buildings. It is necessary to prevent the structure \& services from deterioration and restore it back to its original conditions.

4) Additions and alterations - The works of additions/alterations are carried out in buildings to suit the special requirements of occupants for functional efficiency. The facilities in buildings are updated by carrying out such works.

\subsection{Objectives of Project}

1) To analyze different causes of failure and defects in building and remedies to overcome them.

2) To find out critical maintenance factors and recommend remedies to them.

3) To maximize the aesthetic and economic values of building as well as increase the health and safety of occupants and to extend the useful life of building.

\subsection{Scope of project}

This research focuses on maintenance strategies of residential building to avoid future defects. Identify the critical maintenance work of the components to restore the buildings to its original standards.
Minimize the repair cost of building by implementing proper maintenance strategies. Understand the timely maintenance and repair work of building to extend the life of building.

\section{LITERATURE REVIEW}

In the past many studies has been carried out by various researchers worldwide about the maintenance and repair of building. Some of them are as follows:-

A. Vivian W. Y Tam ${ }^{1}$, Ivan W. H. Fung', Roy C. M. Choi ${ }^{\mathbf{3}}$ (2016) studied common building defects by carrying out, questionnaire survey from building owners as well as professional and building management industry. The result shows that lack of building maintenance knowledge is the fundamental problem encounter by building owners. Lack of awareness, lack of volunteer initiatives of owners and unwillingness of owners to bear the maintenance cost are the three most common reasons for building deterioration.

B. Ajetomobi Oludare Olayinka ${ }^{1}$ and Olanrewaju Sharafadeen Babatunde Owolabi $^{2}$ (2015) states that the common solution to the housing maintenance is the monitoring and documentation of corrective actions, project expenditures, and accomplishments. Followed by provision of accurate data for maintenance and construction programmer decision making, systematically identify maintenance needs, deficiencies, capital improvement needs at housing estates, preparation of service maintenance and construction budget requests using systematic and standardized procedures.

C. N. Ahzahar*1, N.A. Karim², S.H. Hassan ${ }^{3}$, J. $\operatorname{Eman}^{4}$ ( 2011) identified many factors that contributes to the building defects and failures such as -

Climatic Condition, Location of building: Buildings are located near sea or river, Construction material, Building type and change in use: This is because some buildings were built to only hold certain loads and sometimes may not withstand additional loads. Maintenance of building: Repeated maintenance plays a major role in preventing building defects. Faulty design: Reducing size of column, size of reinforcement bar and foundations are the common design error in construction, Lack of supervision. 
D. Nor'Aini Yusofa ${ }^{1}$, Shardy Abdullahb $^{2}$, Sarah Zubedyc', Nurul 'Ulyani Mohd Najibd $^{4}$ (2012) suggests that, "work necessary to maintain the safety and health of residents", "work necessary to keep property habitable" and "work necessary to keep buildings operable" as the most important reasons for maintenance. It also shows that Electrical faults, sanitary appliance failure and pipe linkage are residents top three maintenance priority preferences.

E. Michael N. Grussing ${ }^{1}$, Liang Y. Liu ${ }^{2}$ (2014) states, aging, obsolescence, and general deterioration of buildings and their systems and components can adversely affect the ability to accomplish a mission or generate expected revenue. Without proper investment, buildings will degrade more quickly thus resulting in adverse effects on performance. Building components generally deteriorate over time, causing adverse effects on system function. This results in physical condition loss over time because of age, use, damage, etc.

F. Muhammad Jamaluddin Thaheem ${ }^{1}$ and Alberto De Marco' (2014) indicates, Repair $\&$ maintenance (R\&M) activities of buildings and structures are inescapable: aging, constant use (causing wear and tear), likely defects of design and construction, and the consequences of environmental agents and vulnerabilities cause the deterioration of building components over a period of time. R\&M decisions are partly dictated by policies and regulations in the developed world, however the situation exacerbates in developing countries where large number of externalities dictates these decisions: lack of budget, enforcing regulation and building standards to name a few.

\section{METHODOLOGY AND DATA COLLECTION}

\subsection{Methodology}

1. First and foremost step to begin the project work is the identification of research problem and research objectives is necessary.

2. After finalizing the objectives, extensive literature survey is done. In this, the work done by various authors in past is studied in detail and the procedure carried out by them is analyzed. Further their results, conclusions and findings are also carefully observed.

3. Specific questionnaire is designed.

4. After designing the questionnaire, relevant data is collected from number of residents of building.

5. Analysis of data using SPSS software to find critical maintenance components.

6. Selection of critical maintenance components or major contributing components of maintenance and repair based on criticality index and recommendations for them.

7. Result and discussion.

\subsection{Data Collection}

For this project questionnaire is designed from the study of literature review which consists of fourteen building components, categorized in four different severities namely, Undamaged, Slightly damage, Considerable damage and Severe damage and responses are collected from different building owners. Data is collected from fifteen different sites across Pune area.

Questionnaire survey format

Undamaged $=1$, Slight damage $=2, \quad$ Considerable damage $=3$, Severe damage $=4$

\begin{tabular}{|c|c|c|c|c|c|}
\hline $\begin{array}{l}S \\
r\end{array}$ & $\begin{array}{l}\text { Building } \\
\text { components }\end{array}$ & $\begin{array}{l}\text { Undam } \\
\text { aged }\end{array}$ & $\begin{array}{c}\text { Slig } \\
\text { ht } \\
\text { dam } \\
\text { age }\end{array}$ & $\begin{array}{l}\text { Consid } \\
\text { erable } \\
\text { damage }\end{array}$ & $\begin{array}{c}\text { Seve } \\
\text { re } \\
\text { dam } \\
\text { age }\end{array}$ \\
\hline 1 & Roofs & & & & \\
\hline 2 & Floors & & & & \\
\hline 3 & $\begin{array}{l}\text { Exterior walls, } \\
\text { finishes }\end{array}$ & & & & \\
\hline 4 & $\begin{array}{l}\text { Doors and } \\
\text { windows, } \\
\text { framings }\end{array}$ & & & & \\
\hline 5 & $\begin{array}{c}\text { Interior } \\
\text { finishes/peelin } \\
\text { g paint }\end{array}$ & & & & \\
\hline 6 & $\begin{array}{c}\text { Plumbing and } \\
\text { leakages }\end{array}$ & & & & \\
\hline 7 & $\begin{array}{c}\text { Heating, } \\
\text { Ventilation }\end{array}$ & & & & \\
\hline 8 & $\begin{array}{l}\text { Electrical } \\
\text { lighting }\end{array}$ & & & & \\
\hline 9 & $\begin{array}{c}\text { Cracking } \\
\text { (floor, beam, }\end{array}$ & & & & \\
\hline
\end{tabular}


International Journal of Engineering Applied Sciences and Technology, 2019

Vol. 4, Issue 3, ISSN No. 2455-2143, Pages 432-437

Published Online July 2019 in IJEAST (http://www.ijeast.com)

\begin{tabular}{|c|c|l|l|l|l|} 
& wall) & & & & \\
\hline 1 & Corrosion of & & & & \\
0 & reinforced steel & & & & \\
\hline & Life safety & & & & \\
1 & $\begin{array}{c}\text { requirements } \\
\text { (emergency } \\
\text { exit, warning } \\
\text { systems) }\end{array}$ & & & & \\
\hline 1 & Lift and CCTV & & & & \\
\hline & Common & & & & \\
& access area & & & & \\
1 & (Lobby, & & & & \\
3 & $\begin{array}{c}\text { Pavement } \\
\text { Blocks, }\end{array}$ & & & & \\
& Children play & & & & \\
& area) & & & & \\
\hline 1 & Overhead & & & & \\
4 & water tank & & & & \\
\hline
\end{tabular}

Fig. 2 Output Sheet from SPSS

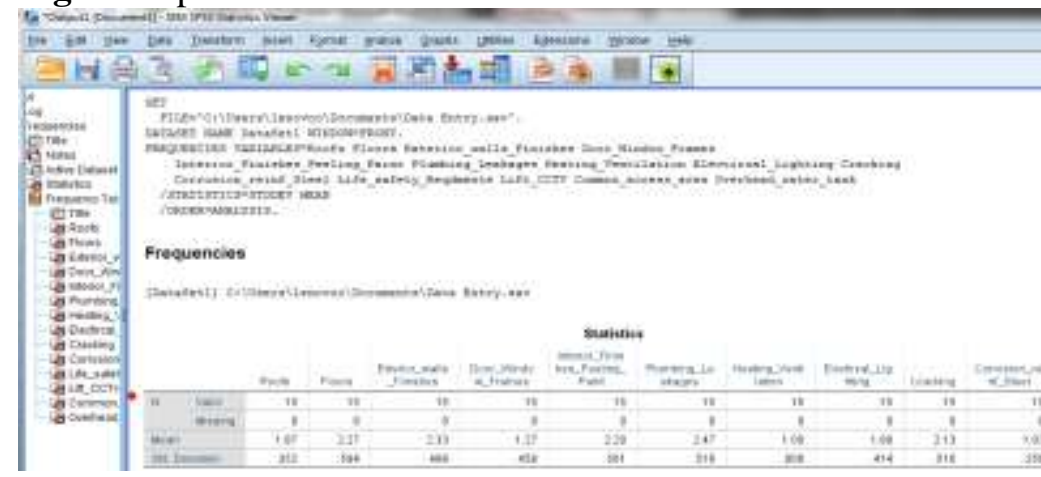

Table 1 Mean of building Components

1) Age of the building

2) Annul amount spent on maintenance

3) Which are the major contributors in maintenance?

3) Period of maintenance work, i.e. Annually/Quarterly or whenever fault is detected

4) Do you practice preventative maintenance? If yes, which are those?

5) What are the challenges in the maintenance and repair work?

6) Number of storey of building

\subsection{Data Analysis}

Based on the above data obtained analysis were done using SPSS software and results were obtained.

Fig. 1 Data Input sheet from SPSS software

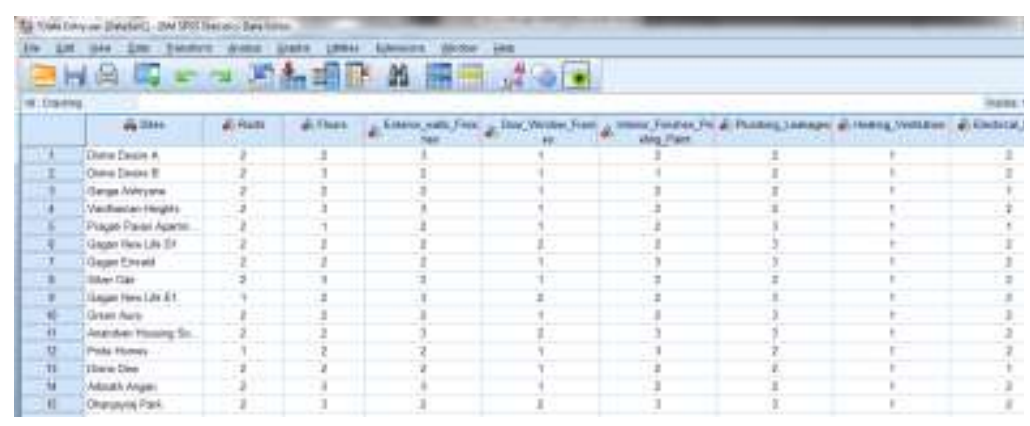

\begin{tabular}{|c|c|c|c|}
\hline $\begin{array}{c}\text { Sr. } \\
\text { No }\end{array}$ & Factors & Mean & $\begin{array}{c}\text { Criticality } \\
\text { Index }\end{array}$ \\
\hline 1 & Roofs & 1.87 & 2 \\
\hline 2 & Floors & & \\
\hline 3 & Door_Window_Frames & 1.27 & 3 \\
\hline 4 & Plumbing_Leakages & & \\
\hline 5 & Interior_Finishes_Peeling_Paint & & \\
\hline 6 & Heating_Ventilation & 1.00 & 3 \\
\hline 7 & Electircal_Lighting & 1.80 & 2 \\
\hline 8 & Cracking & & \\
\hline 9 & Corrosion_reinf_Steel & 1.07 & 3 \\
\hline 10 & Life_safety_Reqdments & 1.20 & 3 \\
\hline 11 & Ovift_CCTV & 1.07 & 3 \\
\hline 12 & Common_access_area & & \\
\hline 13 & Orerhead_water_tank & 1.07 & 3 \\
\hline 14 & Table 2 Criticality _ndex & & \\
\hline
\end{tabular}

Table 2 Criticality index table

\begin{tabular}{|c|c|c|}
\hline $\begin{array}{l}\text { Range of } \\
\text { Mean }\end{array}$ & $\begin{array}{l}\text { Criticality } \\
\text { Index }\end{array}$ & $\begin{array}{l}\text { No of } \\
\text { Components }\end{array}$ \\
\hline $1-1.5$ & 3 & 6 \\
\hline $1.6-2.0$ & 2 & 2 \\
\hline $2.1-2.5$ & 1 & 6 \\
\hline
\end{tabular}


Fig. 3 Bar Chart of the Mean of Components

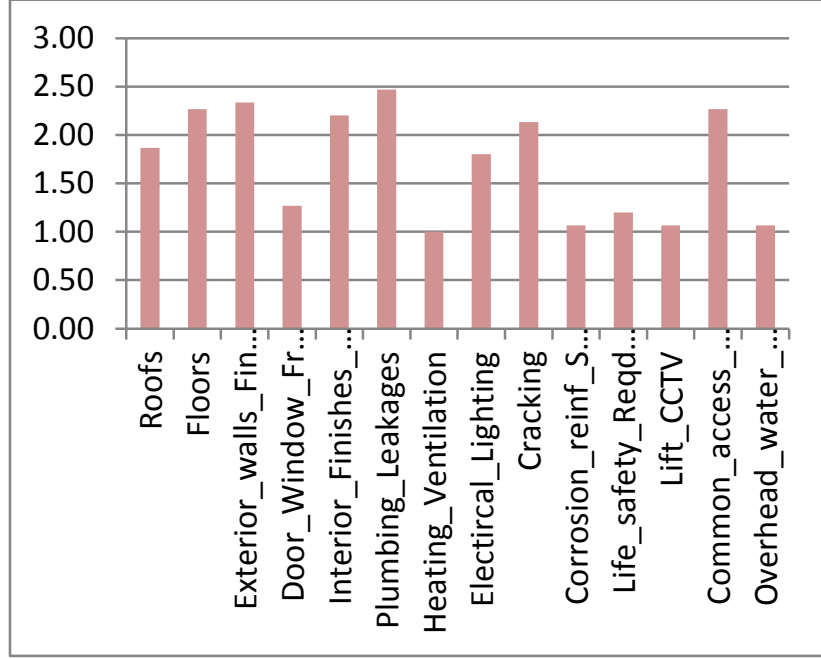

\section{RESULT AND DISCUSSION}

After collecting all the necessary data and doing all the procedures, out of fourteen, six factors are find out to be major contributing in maintenance and repair. This is obtained by means of criticality index, higher the mean value of component, major contribution to maintenance.

As per the analysis of data following six components are critical maintenance components

1) Plumbing and leakages

2) Interior wall and peeling paint

3) Floors

4) Exterior wall finishes

5) Common access area

6) Cracking (floor, beam, wall)

\section{CONCLUSION}

From the results found and study of literature survey we can conclude that there are some building components which contribute more to the maintenance and repair of building. By taking appropriate actions to those components useful life of building can be extended and safety of occupants increased.

\section{REFERENCES}

1. Ahmad Suffian (2013) "Some common problems and building defects : Our Experiences" International conference on Rehabilitation and Maintenance in Civil Engineering

2. Ajetomobi Oludare Olayinka ${ }^{1}$ and Olanrewaju Sharafadeen Babatunde Owolabi ${ }^{2}(2015)$ "Evaluation of the factors affecting housing maintenance and its probable solutions" International Journal of Latest Research in Engineering and Technology Volume 1 Issue 4 September

3. Michael N. Grussing ${ }^{1}$, Liang Y. $\operatorname{Liu}^{2}(2014)$ "Knowledge based Optimization of Building maintenance, Repair and Renovation activities to improve Facility Life Cycle Investments" American Society of Civil Engineers

4. Muhammad Jamaluddin Thaheem ${ }^{1}$ and Alberto De Marco ${ }^{2}$ (2014)"Sustainable Repair \& Maintenance of Buildings in the Developing Countries" Journal of Civil Engineering and Architecture Research Vol. 1, No. 1,

5. N. Ahzahar*1, N.A. Karim ${ }^{2}$, S.H. Hassan ${ }^{3}$, J. (2011) "A Study of Contribution Factors to Building Failures and Defects in Construction Industry" The 2nd International Building Control Conference

6. Nor'Aini Yusofa ${ }^{1}$, Shardy Abdullahb ${ }^{2}$, Sarah Zubedyc', Nurul 'Ulyani Mohd Najibd $^{4}$

(2012) 'Residents' maintenance priorities preference: the case of public housing in Malaysia" WC-BEM 2012

7. Sunday Julius Odediran ${ }^{1}$, Oladele Ayinde Opatunji $^{2}$, Frank O Eghenure $^{3},(2012)$ "Maintenance of Residential Buildings: Users' Practices in Nigeria" Journal of Emerging Trends in Economics and Management Sciences

8. Susan J. Smith ${ }^{1}$, Marja Elsinga ${ }^{2}$, Lorna Fox O'Mahony $^{3}$, Ong Seow Eng', Susan Wachter ${ }^{5}$, Heather Lovell $^{6}$ (2012) "Maintenance and repair" International Encyclopedia of Housing and Home, Vol 4

9. Varinder K. Singh (2012) "Structural Repair and Rehabilitation of multistoried residential building at Chandkheda, Ahemdabad, Gujrat" (NUiCONE 2012)

10. Vivian W. Y Tam ${ }^{1}$, Ivan W. H. Fung ${ }^{2}$, Roy C. M. Choi ${ }^{3}$ (2017) “ Maintenance priority Setting for Private Residential Buildings in 
International Journal of Engineering Applied Sciences and Technology, 2019

Vol. 4, Issue 3, ISSN No. 2455-2143, Pages 432-437

Published Online July 2019 in IJEAST (http://www.ijeast.com)

Hong Kong" American Society of Civil Engineers

11. Nur Liyana Otham ${ }^{1}$, Mastura Jaafar ${ }^{2}$, Fuzaih $\operatorname{Ibrahim}^{3}(2014)$ " A case study on Moisture problems and building defects"
Asian conference on Environmental studies.

12. N. Mohd-Noor 1, M. Y. Hamid ${ }^{2}$, S. N. Haron $^{3}$ (2011) "Building maintenance budget determination" The $2^{\text {nd }}$ International Building Control Conference 